April - 2009

Regional Focus Issue: Bridge over Troubled Waters Cengiz Hakan Aydin and Yoram EshetAlkalai, IRRODL Regional Editors for the Middle East

\title{
Pedagogical and Design Aspects of a Blended Learning Course
}

\author{
Karen Precel, Yoram Eshet-Alkalai, and Yael Alberton \\ The Open University of Israel
}

\begin{abstract}
Based on recent research reports, the blended learning model, which combines face-to-face and online learning, is now the preferred model for online course design. Its superiority over online learning, which lacks face-to-face interaction, is evident from studies that examined both student achievement and satisfaction. Nevertheless, there is ambiguity in the literature and in the field regarding the proper implementation of blended learning and the optimal proportions between online and F2F components in various learning scenarios. The range of contradictory reports in recent literature on the potential of different blended learning models shows the need for more research on specific blended learning courses in order to establish proper standards for effective course design and implementation. The present evaluation study focuses on students' perceptions of pedagogical and design issues related to a new model for blended learning used in a graduatelevel course at the Open University of Israel. Fifty-eight of the course's 91 students participated in the study and completed a questionnaire regarding three major aspects of the course design: (1) pedagogy, (2) textbook format (print vs. digital), and (3) learning environment usability. The results illustrate the importance of completing the pedagogical and visual design of online learning in advance. Also, the course model suggests ways to bridge the gaps between students and instructors and students and their peers, which are typical of online learning in general and of open universities in particular.
\end{abstract}

Keywords: Online learning; blended learning model; usability; pedagogical design

\section{Introduction}

In the past decade, pervasive communication technologies and effective learning management tools have led to the proliferation of online learning for both academic and training purposes (Harasim, 1999; Stephenson, 2001; Herrington, Oliver, \& Reeves, 2003; Bonk, 2004a; b). However, recent studies report that the integration of online learning environments in academia faces a wide range of problems, and the effect of online technologies on the institutes' teaching 
and learning culture is limited (Bonk, Wisher, \& Lee, 2003; Cuban, Kirkpatrick, \& Peck, 2001). According to some studies, the following can explain the limited success of online learning:

\section{Reading from a digital display}

Reading academic text in a digital format is problematic for most learners because of disorientation problems and the low level of ownership that readers have in digital text (Armitage, Wilson, \& Sharp, 2004; Spencer, 2006; Eshet-Alkalai \& Geri, 2007; 2009). Consequently, students' achievements when reading digital text are reported to be lower than their achievements when reading printed text (Ackerman \& Goldsmith, 2008; Ackerman, 2009)

\section{Loneliness}

Students report feelings of loneliness and social detachment when learning online because the physical reinforcement of the F2F learning environment is lacking. These feelings have a negative effect on their learning achievements (Lazenby, 2003; Coates, 2006; Bates \& Khasawneh, 2007; Kurtz \& Amichai-Hamburger, 2008). In most of these reports, learners express the need to bridge the gap with their online instructor and peers.

\section{Digital skills}

Teachers and students lack the necessary cognitive skills for making effective use of online technologies (Eshet, 2004; Eshet-Alkalai \& Amichai-Hamburger, 2004; Eshet, 2007). As pointed out by Shemla and Nachmias (2006), this lack of skills leads to an uneducated use of instructional technologies.

\section{Pedagogic design}

Most academic online learning is perceived as complementary to lecture-based courses, and therefore pedagogical approaches are adopted that fit the traditional, frontal teaching and learning process (Bonk, 2004a; b; Bonk, Graham, \& Moore, 2005; Shemla \& Nachmias, 2006). Consequently, online courses do not usually employ pedagogical approaches that fit online learning (Andrews \& Haythornthwaite, 2007; Bonk \& Graham, 2006; Graham, 2006; Eshet, 2007).

The blended learning model emerged from the above-cited problems (Osguthorpe \& Graham, 2003; Garrison \& Kanuka, 2004; Bonk et al., 2005). Typically, blended learning makes extensive use of learning technologies through the "blend" of physical and virtual environments in order to supplement traditional F2F learning (Singh, 2003; Bersin, 2004; Bonk, 2004a; Rovai \& Jordan, 2004). A wide variety of blended learning models are described in the literature (e.g. Singh, 2003; Thorne, 2003; Bonk et al., 2005), ranging from supplementing the F2F learning process with online materials, as in most traditional universities (Shemla \& Nachmias, 2006), to conducting the learning via a learning management system (LMS) supplemented by a few F2F orientation meetings, which is common in most open or distance universities (Guri-Rosenblit, 2005). Most of the papers on blended learning indicate that there is no ultimate formula for blending the online and F2F learning components and emphasize the challenges faced by designers of blended learning to achieve the best proportion in every learning situation (e.g. Rossett, Douglis, \& 
Frazee, 2003; Bersin, 2004; Dentl \& Motsching-Pitrik, 2005; Rossett, Douglis, \& Frazee, 2003). Garrison and Kanuka (2004) indicate that the transition from traditional F2F to blended learning is not trivial, and they describe the challenges for both students and instructors; nevertheless, they emphasize the great potential of this learning model. In their comparative study of F2F and blended learning, Rovai and Jordan (2004) illustrate the advantages of the latter over the former method in creating a better sense of community without sacrificing high academic standards.

Despite the problems that are involved in the blended learning model, e.g., the need to master a range of digital cognitive skills (Eshet, 2004; Bonk et al., 2006), as of today, it is considered the most effective model for online learning (Osguthorpe \& Graham, 2003; Bonk et al., 2006; Andrews \& Haythornthwaite, 2007). However, although numerous studies have investigated the implementation of the blended learning model, much ambiguity exists regarding its utilization in real-life situations and the optimal proportion of its components in different instructional situations (Bonk, Wisher, \& Lee, 2003; Thorne, 2003; Bersin, 2004; Singh, 2004).

The common model for course design, development, and instruction in most open universities worldwide (e.g., Israel and the UK) contains paradoxes (Guri-Rosenblit, 2005), the most central of which is the fact that courses are developed and written by experts who do not teach them and that the actual instructors of the courses are not involved in writing the textbooks and the learning guides. As pointed out by various scholars (e.g. Guri-Rosenblit, 2005; Lazenby, 2003), this kind of course-delivery model creates a gap between the course developer, the course instructor, and the students and has a negative effect on the learning process and on student satisfaction (Swan, 2001; Bates \& Khasawneh, 2007). Guri-Rosenblit (2005) and Stephenson (2001) emphasize the importance of making special efforts to close this gap in the design of online courses in open universities.

The present evaluation study focused on a graduate-level blended online course at the Open University of Israel in which online learning technologies were used to create an effective and satisfactory online learning environment. This paper presents results from a survey of students regarding the interface and the pedagogic design of the course.

\section{Course Pedagogical Model}

In most of the courses offered at the Open University of Israel, the use of online components in the learning process is relatively limited, consisting mainly of a course homepage, instructor's announcements, syllabus, assignments, occasional online resources, and a forum for online discussions. In most of the courses, the online elements are added to the course after it is developed; they are considered "nice to have," but they are not mandatory or a central element in the learning process. As a result, the online technologies are regarded by students and instructors as add-ons, and they don't affect the learning in the course significantly.

The course investigated in the present study is a graduate-level online course titled Design Principles of Computer-Based Learning Environments. The course focuses on the major aspects of designing technology-based learning environments. Unlike most online courses at the Open 
University, this course is designed as fully online, which means that all learning materials (e.g., lectures, readings, textbook, timetable, assignments, and exercises) are available online, and a major portion of the learning takes place in a specially-designed online learning environment.

The course design and development was based on knowledge of the major problems that underlie online teaching and learning in universities, particularly in open universities (Guri-Rosenblit, 2005). In light of present-day research reports regarding problems that most users face in reading academic texts from digital displays (Eshet \& Geri, 2007), the course textbook is made available to students in both digital and print formats. This allows students to choose their favorite mode of learning for each section in the course and to navigate freely between the text and the online environment. The numerous video lectures by the course writer, which are included in the online course environment, are meant to bridge the above-noted gap between the course writer and the students (Guri-Rosenblit, 2005). The pedagogical design of the course emphasizes a constructivist approach (Bransford, Sherwood, Hasselbring, Kinzer, \& Williams, 1990), in which the learning process focuses on the students' ability to solve real-life problems in an academic context. Accordingly, the course assignments require students to analyze Internet-based learning environments, design user interfaces, and suggest educational simulations to solve real-life learning problems. The course's computerized learning environment (CLE) emphasizes usability standards, navigational flexibility, and design principles for hypertextual learning environments (Balcytiene, 1999).

The course's instruction follows the blended learning model (Bonk et al., 2003; Osguthorpe \& Graham, 2003). It consists of six optional face-to-face orientation meetings, and the remainder of the learning is done online. According to blended learning principles (Bonk et al., 2003), online learning is widely used for topics that emphasize practical issues (e.g., interface design, databases, or simulation design), for which authentic tasks are assigned. On the other hand, for the more theoretical topics (e.g., learning theories), face-to-face learning is dominant.

The course deals with the major aspects of designing computer-based learning environments and their underlying learning processes. The course consists of five learning units: theoretical aspects of learning with technology, hypertext and hypermedia learning environments, user-interface design, designing databases, and educational simulations. Each unit combines a discussion of the theoretical and the practical aspects of the topic. The theoretical background is provided by the assigned articles for each unit and by the course textbook. The course tasks and assignments are designed to help students implement their theoretical knowledge in authentic situations. As noted above, designed as a "virtual classroom," the course's Web site serves as the major learning environment in which discussions take place, the face-to-face meeting summaries are posted, and assignments and tasks are submitted, making the content and the online learning processes inseparable.

\section{Goals of the Study}

As discussed above, knowledge of the major problems associated with online and blended learning (i.e., reading from digital displays, detachment from peers and course instructor, 
mastering digital skills, and inappropriate pedagogical course design) was taken into consideration in designing the blended learning course. Accordingly, the main goals of the present evaluation study were to examine students' perceptions of the following topics:

1. Course pedagogy, including the pedagogical aspects of the online and printed textbook design,

2. Textbook format (print versus digital), and

3. Usability of the course learning environment.

\section{Method}

\section{Participants}

Data were collected anonymously from 58 of the course's 91 students during a period of three semesters in the years 2006-2007 (Table 1). The following demographic information relates to all 91 students: $79 \%$ were females $(n=72)$ and $21 \%$ were males $(n=19)$; their mean age was 39 $(\operatorname{Stdv} 8.2) ; 47 \%(n=43)$ were from central Israel; $45 \%(n=41)$ were from northern Israel; $7 \%(n$ $=6$ ) were from southern Israel; and one was unknown.

Table 1

Distribution of the Study's Participants according to Semester

\begin{tabular}{|l|c|}
\hline \multicolumn{1}{|c|}{ Semester } & \multicolumn{1}{c|}{$\begin{array}{c}\text { Number of } \\
\text { participants }\end{array}$} \\
\hline Fall 2006 & 21 \\
\hline Fall 2007 & 14 \\
\hline Spring 2007 & 23 \\
\hline
\end{tabular}

\section{Tools}

A structured questionnaire was developed in order to examine students' attitudes about the following issues: the course's instructional pedagogy, the technological tools and the learning materials, and the influence of the learning environment design and its contents on learning processes. The questionnaire consists of 78 questions that refer to the students' use of the various learning components, their usability (i.e., friendliness, ease of use, and orientation), and their perceived contribution to learning. Ratings are made on a 1-4 or 1-5 Likert scale for each question, depending on the subject. In some questions, ratings refer to the number of students that used components of the learning management system (LMS) or the frequency of use. The questionnaire, which was distributed during the fall and spring 2007 semesters, was updated to include questions that were absent in the fall 2006 semester. 


\section{Procedure}

Data was collected during three semesters in 2006-2007. The questionnaire was administered in the last F2F meeting or via electronic mail. Students completed the questionnaire either during the meeting, or they completed it online and submitted it via electronic mail. The questionnaire was not part of the course requirements and it was not obligatory to complete it.

\section{Results}

Results are presented in respect to the study's three major goals: (1) course pedagogy (pedagogical aspects of the online textbook's design, online video lectures, and online discussion groups), (2) issues that relate to reading print versus digital text, and (3) usability of the course learning environment (i.e. the online textbook and the course Web site).

\section{Course Pedagogy}

Results relate to three aspects of the course pedagogy: (1) contribution of the overall course components to learning, (2) pedagogical aspects of the textbook and the video lecture design, and (3) the video lectures and discussion groups.

\section{Contribution of course components to learning.}

Students' perceptions of the pedagogical value of various instructional and learning components in the course were examined in the current study. As can be seen in Table 2, the instructional components that were perceived as contributing most to learning were the course tasks (mean $=$ 4.72 ), the printed textbook (mean $=4.54)$, the meeting presentations (mean $=4.42)$, and the F2F meetings $($ mean $=4.15)$. The online video lectures were not found to contribute highly to learning (mean $=3.83$ ); however, 47 out of the 58 participants who answered this question indicated that they would not give them up. The personal notebook (a component in which students can mark selected sections from the online textbook) was the most unused component and was perceived as insignificant to learning (only $7.3 \%$ used it frequently; mean of contribution to learning $=1.6$ ). The online textbook was considered to be an average contributor to learning (mean $=3.32$ ). However, almost half the participants (46.5\%) indicated that they used it frequently.

Table 2

Students' Attitudes toward the Pedagogical Value of Various Instructional and Learning Components

\begin{tabular}{|l|l|l|l|l|l|}
\hline & \multicolumn{3}{|c|}{$\begin{array}{l}\text { Contribution to } \\
\text { learning }\end{array}$} & \multicolumn{2}{l|}{ Frequency of use (\%) } \\
\hline Learning components & $\begin{array}{l}\text { No. of } \\
\text { participants }\end{array}$ & Mean* & Stdv & High** & Low** \\
\hline Online textbook & 56 & 3.32 & 1.42 & 46.5 & 53.5 \\
\hline
\end{tabular}




\begin{tabular}{|l|l|l|l|l|l|}
\hline Printed textbook & 37 & 4.54 & 0.87 & 83.8 & 16.2 \\
\hline Video lectures & 54 & 3.83 & 1.24 & 73.7 & 26.3 \\
\hline Online timetable & 55 & 3.45 & 1.26 & 63.2 & 35.1 \\
\hline Personal notebook & 48 & 1.60 & 1.11 & 7.3 & 92.7 \\
\hline Discussion groups & 53 & 3.51 & 1.12 & 56.1 & 43.9 \\
\hline Meeting presentations & 55 & 4.42 & 0.94 & 86.2 & 13.8 \\
\hline $\begin{array}{l}\text { List of links in the } \\
\text { textbook }\end{array}$ & 55 & 3.93 & 1.09 & 82.5 & 17.5 \\
\hline Tasks*** & 29 & 4.72 & 0.8 & & \\
\hline F2F meetings*** & 26 & 4.15 & 1.26 & & \\
\hline
\end{tabular}

*The answer's scale was $1=$ no contribution $-5=$ high contribution

** High frequency - continuously, frequently; Low frequency - seldom, never

***Items that were not included in the Fall 2006 questionnaire

\section{Textbook and video lecture design.}

The course instruction and the computerized learning environment are based largely on constructivist principles. According to the constructivist approach, knowledge is constructed by engaging students in real-life problem-solving situations (Bransford et al., 1990). Accordingly, the online textbook contains links to brainwork exercises, performance tasks, articles, and authentic examples on the Internet. In the study, students' attitudes to the above components were examined. As Table 3 shows, items 1-3 assessed the extent to which students dwelled upon the brainwork exercises, looked over the recommended examples, or performed the tasks. It was found that the more demanding the tasks, the less students favored them, e.g., a high preference for examples $($ mean $=3.94)$ and a medium preference for performance tasks $($ mean $=3.17)$. Nevertheless, the contribution of these components to students' understanding and motivation was found to be high (mean $=4.2$ ). Note that the components' contribution to learning measure was calculated as a mean of the scores of items 4-9 (Table 3). These items measure the contribution of knowledge construction, relevance to the learning themes, dynamic learning, understanding and internalization of the learning material, gratification from the learning, and the level of interest in the texts. These six items were found to have high internal validity (Cronbach Alpha $=0.91)$. Note that in Table 3, the number of respondents for question 3 was smaller than the other questions. This resulted from the fact that Q. 13 was added to the research during the second semester of the data collection.

\section{Video lectures and discussion groups.}

In order to bridge the gaps between the course developer and the course instructor, between the course instructor and the students, and between the students and their peers, video lectures given by the course developer as well as discussion groups led by the course instructor were included in the computerized learning environment. Most respondents (87\%) indicated that the video lectures were necessary, and more than $90 \%$ reported that they observed at least one lecture. As for the lectures' contribution to learning, the possibility to listen to the lectures combined with the presentation and the examples was found to contribute the most (mean $=4.4$, Table 3 ). 
Almost all respondents (98.2\%) visited the discussion groups. Most of them (67.9\%) reported that they followed the activity continuously in the discussion groups while others visited them occasionally. Of all the respondents, $28.6 \%$ reported active involvement in the discussion groups. The students' satisfaction with the discussions was found to be higher than average (mean = $3.59)$.

Table 3

Students' Attitudes toward the Pedagogy of the Course Instruction and the Influence of the Learning Environment Design and Content on Learning Processes

\begin{tabular}{|c|c|c|c|}
\hline & $\begin{array}{l}\text { Number of } \\
\text { respondents }\end{array}$ & Mean * & Stdv \\
\hline \multicolumn{4}{|l|}{ Exercise components in the textbook } \\
\hline 1. Perform the exercises in the textbook & 48 & 3.17 & 0.97 \\
\hline 2. Stop and think about the questions and issues raised & 47 & 3.40 & 0.90 \\
\hline 3. Stop and examine the examples the text refers to & 48 & 3.94 & 0.81 \\
\hline \multicolumn{4}{|l|}{ Components' contribution to the learning process } \\
\hline 4. Knowledge construction & 47 & 4.15 & 0.81 \\
\hline 5. Relevance to the learning themes & 46 & 4.33 & 0.70 \\
\hline 6. Dynamic learning & 46 & 4.22 & 0.81 \\
\hline 7. The level of interest in the text & 48 & 4.23 & 0.81 \\
\hline 8. Gratification from learning & 48 & 4.21 & 0.82 \\
\hline $\begin{array}{l}\text { 9. Understanding and internalizing the learning } \\
\text { material }\end{array}$ & 47 & 4.15 & 0.81 \\
\hline $\begin{array}{l}\text { Total components' contribution to learning } \\
\text { measure }{ }^{* *}\end{array}$ & 448 & 4.21 & 0.67 \\
\hline $\begin{array}{l}\text { 10. The online textbook's functional design leads you } \\
\text { to refer to, think of, or understand the course content }\end{array}$ & 45 & 3.67 & 1.13 \\
\hline \multicolumn{4}{|l|}{ Video lectures } \\
\hline $\begin{array}{l}\text { 11. The acquaintanceship with the course developer } \\
\text { contributed to the learning experience }\end{array}$ & 50 & 3.78 & 1.18 \\
\hline $\begin{array}{l}\text { 12. The lectures contributed to learning focalization in } \\
\text { each unit }\end{array}$ & 50 & 4.00 & 1.16 \\
\hline $\begin{array}{l}\text { 13. Listening to the lectures combined with the } \\
\text { presentation and examples contributed to } \\
\text { understanding the learning material }\end{array}$ & 32 & 4.40 & 0.80 \\
\hline \multicolumn{4}{|l|}{ Discussion groups (DG) } \\
\hline 14. The satisfaction from the level of discussions & 49 & 3.59 & 0.84 \\
\hline $\begin{array}{l}\text { 15. Organizing the discussion groups according to } \\
\text { units contributed to focalization of discussions in the } \\
\text { DG }\end{array}$ & 49 & 3.96 & 0.96 \\
\hline 16. Organizing the discussion groups according to & 49 & 3.86 & 1.10 \\
\hline
\end{tabular}


units contributed to receiving assistance when needed

*The answer's scale was $1=$ not at all $-5=$ very much

**The measure was calculated as mean of items 4-9 (internal validity, Cronbach Alpha $=0.91)$

\section{Course Textbook: Print versus Digital}

The dilemma over the optimal format for presenting the course learning materials - in a printed or digital textbook - was examined in relation to three different learning assignments: reading, task implementation, and preparation for the final exam (Table 4). As can be seen from Table 4, the general preference of more than half the respondents (57.9\%) was for combining the printed and the digital textbook. Of all the respondents, $36.84 \%$ preferred the printed textbook only, while few students $(5.26 \%)$ preferred the digital textbook only. Table 5 shows that for most of the respondents (more than 60\%), the most influential factors in choosing the printed textbook were the convenience of the printed book, accessibility, and the ease in finding information. The major reasons for choosing the digital textbook were the fast access to online examples of computerbased learning environments and the easy access to links embedded in the text.

Table 4

Students' Preferences Regarding the Textbook Format (printed, digital, or combination) in relation to Various Learning Assignments

\begin{tabular}{|l|c|c|c|}
\hline & $\begin{array}{c}\text { Digital } \\
\text { textbook } \\
\mathbf{\%}\end{array}$ & $\begin{array}{c}\text { Printed } \\
\text { textbook } \\
\mathbf{\%}\end{array}$ & $\begin{array}{c}\text { Combination } \\
\text { \% }\end{array}$ \\
\hline How do you usually read the course textbook? & 10.3 & 50 & 39.7 \\
\hline $\begin{array}{l}\text { Which book do you usually use to prepare the } \\
\text { course tasks? }\end{array}$ & 15.8 & 57.9 & 26.3 \\
\hline $\begin{array}{l}\text { Which book do you prefer to use prior to the final } \\
\text { exam? }\end{array}$ & 14 & 59.7 & 26.3 \\
\hline General preference* & 5.26 & 36.84 & 57.9 \\
\hline
\end{tabular}

* This measure integrates the respondents' preferences of the three learning assignments into one measure in the following way: students who preferred the digital textbook in all assignments = Digital textbook; students who preferred the printed textbook in all assignments $=$ Printed textbook; all other preferences $=$ Combination

Table 5

Print versus Digital - Reasons that Influence the Respondents' Preferences

\begin{tabular}{|l|c|c|c|c|}
\hline & $\begin{array}{c}\text { High/large } \\
\text { influence } \\
\mathbf{\%}\end{array}$ & $\begin{array}{c}\text { Little } \\
\text { influence } \\
\mathbf{\%}\end{array}$ & $\begin{array}{c}\text { No } \\
\text { influence } \\
\mathbf{\%}\end{array}$ & $\begin{array}{c}\text { Number of } \\
\text { respondents }\end{array}$ \\
\hline $\begin{array}{l}\text { It is hard to read long texts from the } \\
\text { computer screen }\end{array}$ & 56.8 & 35.1 & 8.1 & 37 \\
\hline I'm used to reading and studying & 59.5 & 24.3 & 16.2 & 37 \\
\hline
\end{tabular}




\begin{tabular}{|l|c|c|c|c|}
\hline from printed textbooks & & & & \\
\hline $\begin{array}{l}\text { The digital textbook enables easy } \\
\text { access to examples of computerized } \\
\text { learning environments and other } \\
\text { references }\end{array}$ & 62.9 & 22.9 & 14.2 & 35 \\
\hline $\begin{array}{l}\text { The printed textbook can be read } \\
\text { everywhere }\end{array}$ & 64.9 & 24.3 & 10.8 & 37 \\
\hline $\begin{array}{l}\text { It is easy to navigate in the digital } \\
\text { textbook }\end{array}$ & 47.1 & 32.3 & 20.6 & 34 \\
\hline $\begin{array}{l}\text { You can't mark or write notes in the } \\
\text { digital textbook }\end{array}$ & 55.9 & 32.3 & 11.8 & 34 \\
\hline $\begin{array}{l}\text { The digital textbook contains } \\
\text { interesting information that cannot } \\
\text { be found in the printed version }\end{array}$ & 20.0 & 34.3 & 45.7 & 35 \\
\hline $\begin{array}{l}\text { In the printed textbook you can find } \\
\text { what you want easily }\end{array}$ & 62.2 & 29.7 & 8.1 & 37 \\
\hline $\begin{array}{l}\text { The reading in the digital textbook } \\
\text { requires time investment }\end{array}$ & 32.4 & 50.0 & 17.6 & 34 \\
\hline
\end{tabular}

*The answer's scale was $1=$ no influence $-5=$ high/large influence

\section{Usability}

Results indicate the students' high satisfaction with various usability aspects of the CLE (i.e., the ease of use and its friendliness) and the digital textbook. Results in Table 6 show that the organization of the course's digital contents facilitated navigation by leafing through and reading the text (mean = 4.28). High scores were given to specific design elements, such as the font type and size (mean $=3.41$ for both), text organization (mean $=3.46$ ), the integration of tasks and examples in the CLE (mean = 3.64), and the ease of navigation through the text and the CLE (mean $=3.39$ ). The general usability measure, as calculated from items 1-6 in Table 6, was high (mean $=3.5$ ). In addition, the navigation in the CLE, which offers the students flexibility in reaching the course content "from everywhere," was found to be highly usable, and the students used this flexibility wisely and in various ways. For example, half the respondents reached the course readings via the Articles button in the CLE homepage, while 20\% of the respondents reached it via links in the digital textbook or the timetable area in the CLE.

Table 6

Students' Attitudes toward the Design of the Digital Textbook and the Video Lectures

\begin{tabular}{|c|c|c|c|}
\hline & $\begin{array}{l}\text { Number of } \\
\text { respondents }\end{array}$ & Mean * & Stdv \\
\hline \multicolumn{4}{|l|}{ The digital textbook } \\
\hline 1. Text design - chosen font & 46 & 3.41 & 0.62 \\
\hline 2. Text design - font size & 46 & 3.41 & 0.62 \\
\hline
\end{tabular}




\begin{tabular}{|c|c|c|c|}
\hline 3. Text organization in layers & 46 & 3.46 & 0.69 \\
\hline 4. Task integration & 45 & 3.74 & 0.63 \\
\hline 5. Links and examples' integration & 45 & 3.64 & 0.53 \\
\hline 6. Navigation & 44 & 3.39 & 0.75 \\
\hline Total usability measure ${ }^{* *}$ & 46 & 3.50 & 0.50 \\
\hline \multicolumn{4}{|l|}{ The video lectures } \\
\hline 7. Functional design of the video lecture interface & 49 & 3.45 & 0.68 \\
\hline 8. Time length of the video lectures & 48 & 3.25 & 0.86 \\
\hline
\end{tabular}

\section{Discussion and Conclusions}

Results of the current evaluation study make a meaningful contribution to our understanding of the perceived value of learning and instruction in online environments, especially in light of the numerous studies that indicate the need to refine our understanding of the usability and pedagogical aspects of blended learning (Thorne, 2003; Bersin, 2004; Bonk et al., 2005). The high rating in the study of the course's pedagogical and design elements illustrates the great importance of "designing in advance," which takes into account the problems of online learning, contrary to "designing in retrospect," which characterizes the majority of present-day online academic courses (Shemla \& Nachmias, 2006).

The finding that students' strongly preferred the blended learning model is in agreement with reports from most current studies on online learning models (e.g. Throne, 2003, Singh, 2004, Bersin, 2004, Bonk et al., 2005). Our findings illustrate the need to adjust the instructional model to the content and the learning objectives, as discussed by Guri-Rossenblit (2005) and Bonk and Graham (2006). Findings of the current study indicate students' high evaluation of the interactive learning components, such as discussion groups and constructivist tasks, which is in agreement with other studies that explored the value of students' engagement and interactivity in the online process (Herrington et al., 2003; Bonk, 2004a; b; Coates, 2006; Allen \& Seaman, 2007).

Results of the current study reinforce the widely-reported student preference for reading academic texts in print over reading them in a digital display (Spencer, 2006; Eshet-Alkalai \& Geri, 2007; 2009) due to its ease of navigation and high availability. Only a few students preferred the digital over the printed textbook, mainly because of the accessibility it provides to the online examples. It should be noted that other studies (e.g. Eshet-Alkalai \& Geri, 2007) indicate that the capability of readers of various age groups to deal with critical reading of digital texts in various knowledge domains is yet unclear, emphasizing the need for solid research data in order to reach conclusions regarding the preferred format in reading academic texts.

The current study found high satisfaction with the usability components of the CLE, which is exceptional compared to the general low satisfaction with LMS sites reported in many studies (e.g. Swan, 2001; Bonk, 2004a; b; Shemla \& Nachmias, 2006). Extremely high satisfaction (mean $=4.7$ on a 1-5 scale) with the CLE was also found in the course instruction surveys that 
were given to students at the end of each semester. We believe that this high satisfaction rate is an outcome of the major investment in designing the pedagogical and usability elements of the course "in advance," as suggested by Guri-Rosenblit (2005). Nevertheless, the usability of some components (i.e., the personal notebook) was evaluated as low. Therefore, further research is needed to clarify the reasons for these evaluations and adapt the course design accordingly.

The current study has some limitations: (1) the sample was small, (2) participants were MA students in an educational technology graduate program, and many of them have higher computer skills than the average student, so the high level of satisfaction found in the research might not represent students from other disciplines, and (3) even though the questionnaire used in the study was modified from the Open University's standard instruction satisfaction questionnaire, it did not undergo a large-scale validation process.

In futures studies, after validating the questionnaire, special emphasis should be placed on testing a larger group, comparing students' attitudes from various disciplines and proficiency levels, and comparing online courses that are based on different pedagogical models. Notwithstanding, results of the current study shed new light on our understanding of the proper design of a blended online academic course by highlighting the need for in-advance pedagogical and visual design. In addition, results indicate the potential of the current model to bridge the gaps between students and instructors and students and their peers, which are typical of online learning, and to create meaningful learning by employing online pedagogical consideration in the course design. 


\section{References}

Ackerman, R. (2009). The subjective feelings of comprehension and remembering accompanying text-learning on-screen. In Y. Eshet, A. Caspi, S. Eden, N. Geri, and Y. Yair (Eds), Learning in the Technological Era III: Proceedings of the 2009 Chais Conference (pp 1- Page | 13 7). Raanana: The Open University of Israel.

Ackerman, R. \& Goldsmith, M. (2008). Learning directly from screen? Oh-no, I must print it! Metacognitive analysis of digitally presented text learning. In Y. Eshet, A. Caspi, N. Geri, (eds), Learning in the Technological Era III: Proceedings of the 2009 Chais Conference (pp. 1-7). Raanana: The Open University of Israel.

Allen, I. E. \& Seaman, J. (2003). Sizing the opportunity: The quality of online education in the United States, 2002 and 2003. MA: The Sloan Consortium. http://www.aln.org/resources/sizing opportunity.pdf

Andrews, R. \& Haythornthwaite, C. (2007). The sage handbook of e-learning research. L.A: Sage Publications.

Armitage U., Wilson, S., \& Sharp, H. (2004). Navigation and ownership for learning in electronic texts: An experimental study. Electronic Journal of E-Learning, 2(2): http://www.ejel.org/volume-2/vol2-issue1/issue1-art17.htm.

Balcytiene, A. (1999). Exploring individual processes of knowledge construction with hypertext. Instructional Science, 27, 303-328.

Bates, A.R. \& Khasawneh, S. (2007). Self efficacy and college students' perception and use of online learning systems. Computers in Human Behavior, 3(1), 175-191.

Bersin, J. (2004). The blended learning book: Best practices, proven methodologies and lessons learned. New York, NY: Wiley \& Sons

Bonk, C. J. (2004a). The perfect e-storm: emerging technology, enormous learner demand, enhanced pedagogy, and erased budgets. Part 1: Storms \# 1 and \#2. The Observatory on Higher Education, 2004, [On-line]. http://www.obhe.ac.uk/products/reports/publicaccesspdf/Bonk.pdf

Bonk, C. J. (2004b). The perfect e-storm: emerging technology, enormous learner demand, enhanced pedagogy, and erased budgets. Part 2: Storms \# 3 and \#4. The Observatory on Higher Education, 2004, [On-line]. http://www.publicationshare.com/part2.pdf.

Bonk, C. J. \& Graham, C. R. (Eds.) (2006). Handbook of blended learning: Global perspectives, local designs. San Francisco, CA: Pfeiffer Publishing. 
Bonk, C. J., Wisher, R. A., \& Lee, J. (2003). Moderating learner-centered e-learning: Problems and solutions, benefits and implications. In T. S. Roberts (Ed.), Online collaborative learning: Theory and practice (pp. 54-85). Idea Group Publishing.

Bransford, J. D., Sherwood, R. D., Hasselbring, T. S., Kinzer, C. K., \& Williams, S. M (1990). Anchored instruction: Why we need it and how technology can help. In C. Nix \& R. Page $\mid 14$ Spiro (Eds.), Cognition, Education and Multimedia: Exploring Ideas in High Technology (pp. 115-141). Hillsdale, NJ: Lawrence Erlbaum Associates.

Coates, H. (2006). Student engagement in campus-based and online education. London:

Routledge.

Cuban, L., Kirkpatrick, H., \& Peck, C. (2001). High access and low use of technology in high school classrooms: Explaining an apparent paradox. American Educational Research Journal, $38(4), 813-834$.

Derntl, M. \& Motschnig-Pitrik, R. (2005). The role of structure, patterns, and people in blended learning. The Internet and Higher Education, 8(2), 111-130.

Eshet, Y. (2004). Digital literacy: A conceptual framework for survival skills in the digital era. Journal of Educational Multimedia and Hypermedia, 13(1), 93-106.

Eshet, Y. (2007). Teaching online: survival skills for the effective teacher. Inroads-The SIGCSE Bulletin, 39(2), 16-20.

Eshet-Alkalai Y. \& Geri, N. (2007). Does the medium affect the message? The influence of text representation format on critical thinking. Human Systems Management, 26(4), 269-279.

Eshet, Y. \& Geri, N. (2009). Congruent versus incongruent display: The effect of page layout on critical reading in print and digital formats. In Y. Eshet, A. Caspi, S. Eden, N. Geri, \& Y. Yair (Eds.), Learning in the Technological Era IV: Proceedings of the 2009 Chais Conference, 2 February 2009 (pp. 73-80). Raanana: The Open University of Israel.

Graham, C. R. (2006). Blended learning wystems: Definition, current trends, and future directions. In C.J. Bonk \& C.R. Graham (Eds.), Handbook of blended learning: Global Perspectives, local designs. San Francisco, CA: Pfeiffer Publishing.

Harasim, L. (1999). A framework for online learning: the Virtual-U. Computer, 9, 44-49.

Herrington, J., Oliver, R., \& Reeves, T. (2003). Patterns of Engagement in authentic online learning environments. Australian Journal of Educational Technology, 19(1), 59-71.

Garrison, D. R. \& Kanuka, H. (2004). Blended learning: Uncovering its transformative potential in higher education. The Internet and Higher Education, 7(2), 95-105. 
Guri-Rosenblit, S. (2005). Eight paradoxes in the implementation process of e-learning in higher education. Higher Education Policy, 18, 5-29.

Kurtz, G. \& Amichai-Hamburger, Y. (2008). Psychological well-being and attitudes toward elearning. In Y. Eshet, Y., A. Caspi, \& N. Geri (Eds.), Learning in the Technological Era III: Proceedings of the 2009 Chais Conference (pp. 60-65). Raanana: The Open University of Israel.

Lazenby, K. (2003). Technology and educational innovation: A case study of the virtual campus of the University of Pretoria. Doctoral dissertation. The University of Pretoria: Pretoria, South Africa [Online]. http://upetd.up.ac.za/thesis/available/etd-03172003-094954

Osguthorpe, R.T. \& Graham, C. R. (2003). Blended learning environments: Definitions and directions. The Quarterly Review of Distance Education, 4(3), 227-233.

Rossett, A., Douglis, F., \& Frazee, R.V. (2003). Strategies for building blended learning. Alexandria, VA, USA: ASTD Learning Circuits.

Rovai, A. \& Jordan, H. M. (2004). Blended learning and sense of community: A comparative analysis with traditional and fully online graduate courses. The International Review of Research in Open and Distance Learning, 5 (2) [On-line]. http://www.irrodl.org/index.php/irrodl/article/viewArticle/192/274.

Shemla, A. \& Nachmias, R. (2006). How do lecturers integrate the Web in their courses? Websupported courses at Tel-Aviv University. In E. Pearson \& $\mathrm{P}$ Bohman (Eds.), Proceedings of World Conference on Educational Multimedia, Hypermedia and Telecommunications 2006 (pp. 347-354). Chesapeake, VA: AACE.

Singh, H. (2003). Building effective blended learning programs. Educational Technology, 43(6), 51-54.

Spencer, C. (2006). Research on learners' preferences for reading from a printed text or from a computer screen. Journal of Distance Education, 21(1), 33-50.

Thorne, K. (2003). Blended learning: How to integrate online and traditional learning. London: Kogan Page.

Stephenson, J. (2001). Teaching and learning online: Pedagogies for new technologies. London: Routledge.

Swan, K. (2001). Virtual interactivity: Design factors affecting student satisfaction and perceived learning in asynchronous online courses. Distance Education, 22(2), 306-331. 
